\title{
「供給者による需要誘発」抑止の メカニズムとしての管理医療保険モデル
}

國學院大學経済学部 助教授

中 泉 真 樹

はじめに

1980年代，米国の医療サービス，医療保険の市場は大きな变革期を迎え た。公的部門ではメディケア，メディケイドにおけるPPS (Prospective Payment System）の導入であり，民間部門では管理医療保険プラン市場 の急成長と多様化である (印南 (1988), 中西他 (1991) の4節)。そし て90年代，政権交代とと屯に国民皆保険を目指す医療システムの抜本的改 革がきわめて重大な政治的争点となりつつある。このように急展開している 状況を念頭にしつつも，小論の目的は，管理医療保険型のプランがなぜ消費 者（被保険者）ばかりでなく医師，医療機関によって抵抗なく受け入れられ るか，その理由を簡単な経済学の手法で分析することにある。

周知のように，医療サービスは標準的な経済理論の域を越えた特殊性を持 つといわれるが，それは消費者（患者）之供給者（医師）の間に介在する情 報の非対称性の問題に関連している。消費者が医療サービスの購入（受診） を決意する背景には，なんらかの異常な自覚症状を持つか，あるいは健康状 態に対する不安を覚えているということがあろう（これは健康状態（サービ スの必要性）に関するノイズを含んだシグナルである)。そのさい医師に求 められているのは状態についての正確な診断であり，その診断結果に即して 行われる適切な治療である。ところが消費者は，そあそもどのような診断を 受けるべきか判断する医学的知識を持ちあわせていないばかりではなく, 診 
断の事後，その結果を評価する，したがって今後どのような処置・治療を受 けるべきか評価するための十分な知識を持っていないという意味で，情報不 足に直面している。こうした情報の非対称性によって，消費者のニーズとは 独立に，医師には裁量的に（機会主義的に）診断や治潦に対する需要を操作・ 創出することが可能になるのである ${ }^{1)} 。$

かかった医療費分すべてが医師，医療機関に支払われる出来高制の報酬制 度を含む従来の保険システムは，医師の裁量権を際限なく保証するシステム であったということができ，1980年代に現れた変革の流れはこうした従来 型にかわる効率的システムを模索する渦中にあったとみなすことができるだ

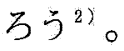

しかしながらことにPPO (Preferred Provider Organization) に代 表される新しいタイプの保険プランが従来のシステムのもとで裁量権を保証 された医師によって自発的に受容される背景が，経済理論に照らして十分に 分析されてきたとはいいがたく，したがって小論の目新しさはその点に関す るささやかな追求である。

アイデアはきわめて単純である。消費者に自己の選好もしくはニーズを診 断する能力はなく，かたや供給者にはそうした能力が備わっているような財・ サービスの (売り手) 独占市場を考えよう。供給者は消費者に真の選好を伝 達することでその消費者の購入確率が低下するとしても, 留保価格の高い消 費者を選別して供給することが可能であり，販売価格を引き上げることがで

1）医療サービスに代表される財・サービスの市場に関して理論的分析を行った文献は, Arrow (1963) 以来必ずしも多くはないが, Darby and Karni (1973), 最近ではWolinsky （1993）がある。Wolinskyは，このような財の競争市場において，消費者に不必要なサー ビスを提供して利得を稼ぐという供給者の機会主義的行動が，消費者による費用をかけた 探索か評判効果のいずれかによって抑止されるメカニズムを分析している。なお，医療サー ビス市場における供給者による需要誘発に関する代表的文献としてはEvans（1974）がよ く知られている。

2) Enthoven（1988）は, 従来のシステムの特性を批判的に整理した上で, 彼の提案する管 理競争 (managed competition) に基づく医療システム改革について包括的に述べてお り，改革の流れに無視しえない影響を及ぼしつつある。 
きるだろう。それによってむしろ高利潤を確保しうるかもしれないのだが， 真の選好を伝達するという行為は明らかに credible ではない。つまり真の 選好を伝達し, 留保価格の高い消費者のみに相対的に高価格で販売するとい う戦略は採用されえない。なぜなら留保価格の低い（この財に対するニーズ の低い）消費者にもその必要性を説得して同じ高価格で購入させる誘因が存 在するのである。それゆえ消費者は供給者による診断を信頼せず，均衡では credible な情報伝達が起こらないまま相対的に低い一律価格でニーズの低 い（無い）消費者にあ供給がなされるのである。まさしくこれは需要誘発の メカニズムを表すひとつのシナリオであるが，こうしたトラップを回避する ためにこそ，たとえ診断が重複されるとしてあ，供給者の利害とは独立した 主体（保険者）によって消費者ニーズの審査が行われることが不可欠となる のである。保険者はこうした審査機構と供給価格の設定を含む契約を供給者 に提示する。すしこのような契約によって供給者の利得と消費者の厚生を従 来よりあ高めうれば，保険者は供給者を傘下に確保し，同時に（保険プラン 市場での競争に打ち勝って）消費者（顧客）を獲得できるはずである。そし て, 審查精度に依存する審査費用関数の形状しだいでこのシナリオの実現可 能であることが，容易に検証されるのである。新しいタイプの保険プランは， 供給者による需要誘発が有効に抑止されるメカニズムを内包していると解釈 されよう。

小論の構成は次のとおりである。

1. では上に述べた供給者による需要誘発のメカニズムをできるだけ単純 なモデルで説明する。2, では, 需要誘発の問題が保険者による消費者二ズの審査によっていかに回避（緩和）されるか明らかにする。3．は消費者 タイプ（選好）に多様性を導入する方向にモデルを拡張して分析を行う。 4. では小論の分析結果を要約し, さらなる拡張の可能性を示唆した上で結びと したい。

\section{1. 供給者による需要誘発のモデル}

消費者がある財・サービスに対する自分の選好むしくはニーズについて十 
分な知識を持っていない状沉で, 供給者が独自の目標関数に基づいて需要を 誘発させる，きわめて単純なモデルを構築しょう ${ }^{3)}$ 。さしあたって消費者の 所得，選好等はすべて同じとし，タイプの多様性を捨象する。消費者は当該 財を購入するか，しないかを決定し，購入するのであれば 1 単位のみ購入す るとして，この財と貨幣（その他の一般財）に対する加法的な効用関数 $U=$ $\mathrm{u}(\mathrm{y})+\mathrm{x}$ を持つと想定しよう。 $\mathrm{y}$ は貨幣の消費量， $\mathrm{x}$ はこの財を 1 単位消 費することで発生する効用である（むし購入しないのであれば， $\mathrm{x}=0$ であ る)。ここで u' $(y)>0$ かっ u’ (y)<0 を仮定する ${ }^{4)}$ 。後者は, 消費者が貨 幣所得の変動に対して危険回避的な態度を持っていることを意味している。 財の購入に関わって消費者のおかれる状態（state）は二通りである。ひと つはその財を 1 単位消費することによって正の効用 $\mathrm{x}=\mathrm{V}-\mathrm{s}>0$ が発生 する場合で，これを状態 1 としょう。もうひとつはゼロむしくは負の効用 $\mathrm{x}=-\mathrm{s} \leqq 0$ が発生する場合で, 状態 2 とする。このように仮定すると, 選好の指標のひとつである $\mathrm{s}$ は, 各状態とは独立に消費にともなって負担さ れる非金銭的な機会費用であり，ホテリングの空間競争モデル (Hotelling's spatial competition model）における企業立地点までの交通費用に相応し ている。あるいは供給者のタイプがどれだけ消費者の好みに合っているかを 示していると考えることができる $(\mathrm{s}=0$ ならば，この供給者は状態 1 の消 費者にとっての理想タイプである)。自己のおかれた状態についての正確な 知識を持つのであれば，消費者がこの財を購入するのは明らかに状態 1 の場

3) 以下で明らかになるように, 小論の分析では一貫して供給者は（期待）利潤最大化の主体 であると仮定されるが，医療サービス市場の供給の担い手，医師についてこの仮定を適用 することには批判が予想されよう。たしかに医師の目標関数には，患者の効用やある特定 の診療行為への突出した（それが学問上の業績に関連しているための）選好なども反映さ れてしかるべきであろう。しかし採算性への関心や所得動機もまた医師の行動を規定する 面があり，需要誘発行動を引き起こす要因をなすのである。こうした面がある限り，小論 での分析は医師がより一般的な目標関数を持つ場合に応用することは可能であり，ここで はむしろ利潤最大化仮説によってこそ明快な分析結果を生むことができるのである。

4）以下で 1 変数関数の上肩に記した「’」は 1 階の微分を,「”」は 2 階の微分をそれぞれ表す あのと約束する。 
合であり，しかす購入することによる効用がしないことによる効用を上回る ときに限る。購入に先立つ所得を $\mathrm{Y}$ ，この財の価格を $\mathrm{P}$ とすれば，購入の条 件は， $\mathrm{u}(\mathrm{Y}-\mathrm{P})+\mathrm{V}-\mathrm{s} \geqq \mathrm{u}(\mathrm{Y})$ となる（便宜のため無差別の場合も購 入すると仮定する)。しかしながら状態について不確実なことしかわからな く，たとえばこの消費者が確率 $\mathrm{f}(0<\mathrm{f}<1)$ で状態 1 におかれていると いうシグナル（この財が医療サービスであれば，健康状態についての不安や 異常と思われる自覚症状) だけを受け取っていると想定してみよう。消費者 が購入を決意する条件は， $\mathrm{u}(\mathrm{Y}-\mathrm{P})+\mathrm{fV}-\mathrm{s} \geqq \mathrm{u}(\mathrm{Y})$ となる。したがっ て消費者がこの財に対して支払ってもよいと考える留保価格は，選好の不確 実性によって低下すると考えられる。

このモデルで供給者による需要誘発の仕組みを分析してみよう。供給者が 利潤を追求する独占者であれば，消費者が直面する選好の不確実性は設定可 能な独占価格の低下を意味する。もし供給者が顧客の選好もしくはニーズに ついての情報を持っているのであれば，それを正直に顧客に伝達することに よって留保価格を高め, 利潤の増大をはかることが可能かもしれない。にも かかわらず情報の伝達は起こらず，したがって不確実性は解消されないまま, 結果的に状態 2 での消費は排除されない。このメカニズムは次のように説明 される。

この財を生産するための限界費用を c とし, 消費者数を 1 に標準化する。 消費者の選好を正しく伝達することを表明し, 消費者がそれを文字通り受け 取るとすれば，独占価格 $\mathrm{M}^{*}$ は $\mathrm{u}\left(\mathrm{Y}-\mathrm{M}^{*}\right)+\mathrm{V}-\mathrm{s}=\mathrm{u}(\mathrm{Y})$ によって与元 られる。このとき, 供給者が事前の表明にしたがって行動し, 状態 1 の消費 者のみに供給するのであれば， $\left(\mathrm{M}^{*}-\mathrm{c}\right) \mathrm{f}$ の利潤を得るが，表明に反して 状態 2 の患者にも供給（需要を誘発）すれば， $\mathrm{M}^{*}-\mathrm{c}$ の利潤を獲得できる。 次にあしその表明を消費者が信頼しないとすれば，独占価格 $\mathrm{M}^{* *}$ は $\mathrm{u}(\mathrm{Y}-$ $\left.\mathrm{M}^{* *}\right)+\mathrm{fV}-\mathrm{s}=\mathrm{u}(\mathrm{Y})$ によって与えられ，独占価格を $\mathrm{M}^{* *}$ に設定すれば $\mathrm{M}^{* *}-\mathrm{c}$ の利潤を得るが，もし消費者の信頼を前提に $\mathrm{M}^{*}$ を付ければ， $\mathrm{M}^{*}>\mathrm{M}^{* *}$ ，つまり留保価格を上回る価格付けによって顧客は失われ，利潤 は得られない。このとき興味あるのは，上で示唆したような $\left(M^{*}-c\right) f>$ $\mathrm{M}^{* *}-\mathrm{c}$ の場合である。消費者側の (期待) 余剩はいずれの場合むゼロで 
あるが，選好の正直な伝達という表明が消費者に信頼され，表明通りにそれ を実行するならば，利潤の増大があたらされる。ところがあし消費者がこの 表明を信頼すれば，明らかに正直な伝達は発生しない。状態 2 の消費者にす 状態 1 であると伝達して需要を喚起させ, 利潤を増大させることが可能であ る。このとき消費者の期待余剩は負となるので，もし消費者が合理的に供給 者の誘因を推測すれば， $\mathrm{M}^{*}$ での購入は控えるであろう。したがって供給者

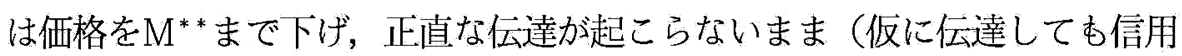
されないまま)，どの状態にある消費者あ購入することになる5 。

このメカニズムは，買い手が売り手の選択する財の品質を観察できずに購 入する状況で発生するモラル・ハザードと本質的に同じである。売り手が高 品質と宣伝して高い価格を設定してあ，この宣伝は credible ではない。売 り手には品質を低め, 費用を節減させる誘因が存在している。買い手の購買 行動がこの誘因を考慮したものであれば，低価格で低品質財の取引が起こる か，そもそあ市場が潰れてしまうかのいずれかである（Tirole (1988) ch. 2)。 したがって供給者による誘発需要は, 情報の偏在があたらすモラル・ハザー ドの典型問題をなしているといえよう。

\section{2. 需要誘発の問題はいかに解消されるか}

需要誘発のメカニズムはいわば「囚人のディレンマ」の性格を持ち, 消費

5) 以上の分析では，供給者が正直な情報伝達を行う場合にはそれを確率 1 で行うことが前提 されたが，より一般的に，状態 2 の消費者に 1 - h の確率で正直な伝達を行うと考えるこ とができる。情報伝達戦略 1 - $\mathrm{h}$ とそれに基づく価格設定 $\mathrm{P}$ に供給者が事前に commit きるのであれば, 供給者の問題は, 状態 1 という診断を受けた消費者の期待効用が非購入 の効用を下回ることはないという次の制約条件,

$\mathrm{u}(\mathrm{Y}-\mathrm{P})+\mathrm{fV} /\{\mathrm{f}+(1-\mathrm{f}) \mathrm{h}\}-\mathrm{s} \geqq \mathrm{u}(\mathrm{Y})$

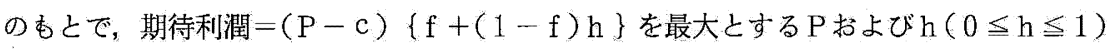
を選択することである。この問題の解は一意に存在することが容易に示される。また正直 な伝達の確率が正值をとるための必要十分条件が fV/ $\left(\mathrm{M}^{* *}-\mathrm{c}\right)-\mathrm{u}^{\prime}\left(\mathrm{Y}-\mathrm{M}^{* *}\right)>0$ と なることを確認できる。しかしながらこの条件のもとで得られる正の最適伝達率 $\mathrm{h}^{*}$ と価格 $\mathrm{P}^{*}$ は, $\left(\mathrm{P}^{*}-\mathrm{c}\right)>\left(\mathrm{P}^{*}-\mathrm{c}\right)\left\{\mathrm{f}+(1-\mathrm{f}) \mathrm{h}^{*}\right\}$ によって明らかに credibleではない。 
者の選好を正直に伝達するという供給者の表明が credibility を欠くことが 問題である。こうした状況を解决して供給者と消費者の双方に利益となるメ カニズムを見い出すことが次の課題となる。そこで消費者の利害を代弁する か，あるいは中立的な態度を持つ経済主体にそのメカニズムを担わせるので ある。当該財の代表的な典型を医療サービスと考え，この経済主体を保険者 と呼ぶことにしょう。誘発需要抑止に本質的な保険者の役割は，消費者の選 好を調查し, その財の購入が選好にかなったあのかどうかをチェックするこ 之である。医療の文脈では，ある処置，手術等に先立って，それらが患者の ために本当に不可欠なあのかを審査することである。こうした作業を供給者 本人ではなく，その利害と独立している保険者が担うことによって credibility の問題は解決されるはずである。このような審查機構と価格付けを含 む保険者による契約の申し出を，はたして供給者が受け入れるかどうか，そ れを以下で検討しょう。

選好についての審査の精度と費用の関係を次のように指定する。消費者 1 人あたり $\mathrm{k}(\mathrm{a})$ の費用を投じることにより, 確率 $\mathrm{a}$ で各消費者の選好につい ての確かな情報が得られるとしよう。残りの 1 - $\mathrm{a}$ は何の情報屯得られない まま，財の供給を供給者の裁量に委ねることになる確率である。a はいわば 審査の精度であり，それを高めることは費用の増大をあたらす。 $\mathrm{k}(0)=0$ ， $k^{\prime}(a)>0$ 抢よび $k ”(a)>0$ を仮定し, さらに $\lim _{a \rightarrow 1} k^{\prime}(a)=\infty$ としょう。 後者は審査の限界費用が精度の上昇につれて莪増し, 確率 1 で正確な情報を 得ることが困難であることを意味している。

保険者が供給者に提案し, 交涉の対象となる契約は価格 $\mathrm{P}$ と審査の精度 $\mathrm{a}$ からなる。あし契約が成立するのであれば，保険者の残された作業は，審査 の結果状態 2 之認められ財の供給を受けない消費者と, 状態 1 と見分けられ るか，あるいは何の情報む得られないまま購入することになる消費者の間の 事後所得が等しくなる，むしくは貨幣の限界効用が等しくなるように費用を 分担させ，危険分散を図ることである。各消費者の初期貨幣保有量をYとす れば，消費者の受け取る事後所得は， $y=Y-(1-a(1-f)) P-k(a)$ であり，消費者の期待効用は $\mathrm{u}(\mathrm{y})+\mathrm{fV}-(1-\mathrm{a}(1-\mathrm{f})) \mathrm{s}$ となる。一方 で供給者の利潤は $(P-c)(1-a(1-f))$ となる。先の独占均衡は $a=$ 
0 かつ $\mathrm{P}=\mathrm{M}^{* *}$ の場合である。 $\mathrm{M}^{* *}-\mathrm{c}$ を上回る利潤を産み出し，かつ正 の消費者余剰が発生する，すなわち $\mathrm{u}(\mathrm{y})+\mathrm{fV}-(1-\mathrm{a}(1-\mathrm{f})) \mathrm{s}>\mathrm{u}(\mathrm{Y})$ となる契約が存在するかどうかを検討してみるには，供給者と消費者の契約 曲線を特性化すればよい。契約曲線は，供給者の利潤がある与えられた水準 を下回らないことを制約として，消費者の期待効用を最大とする価格および 審查の精度を求めることで導出される。

図 1

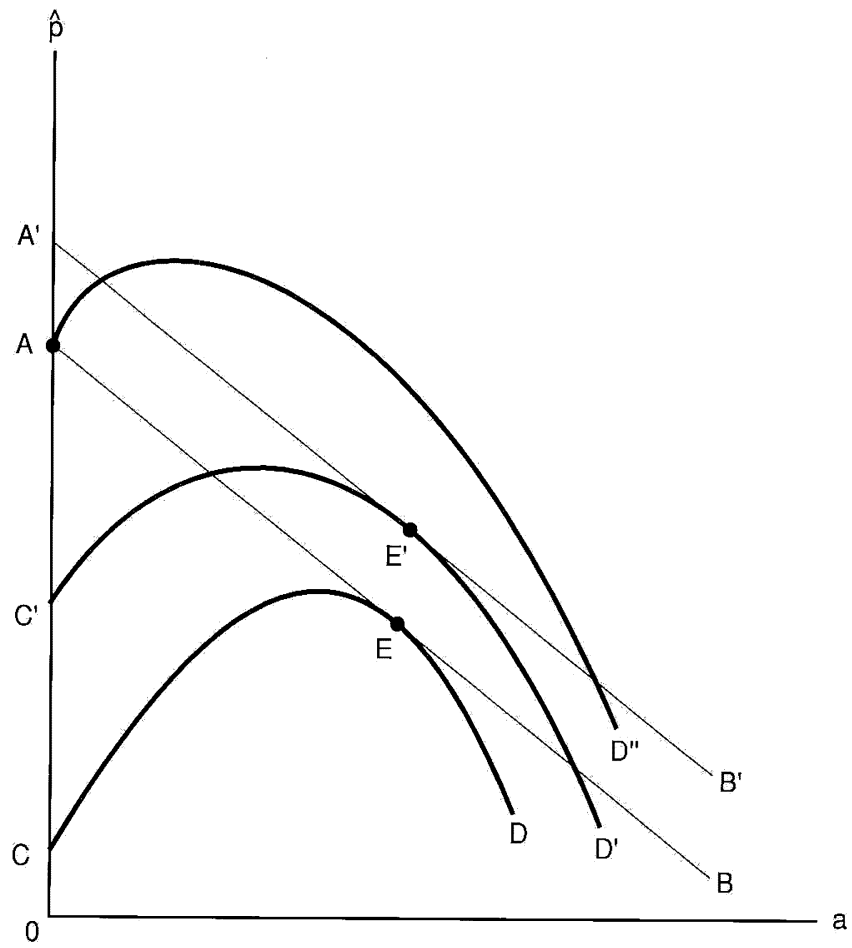

解は図 1 に描かれる。図 1 で縦軸は供給者の期待収入 $\hat{\mathrm{P}}=\mathrm{P}(1-\mathrm{a}(1-$ f)，横軸は審査の精度 a 表す。傾きが $-(1-f) c$ である線分 A B, $\mathrm{A}^{\prime} \mathrm{B}^{\prime}$ は供給者の等利潤曲線であり, 右上に位置するほど利閏が高い。一方, 曲線 CD，C $\mathrm{C}^{\prime \prime}$ ，および $\mathrm{AD}$ ” は消費者の期待効用の無差別曲線であり， 下に凹となるように仮定されている。そして下方に位置する無差別曲線ほど 効用水準は高くなる。このとき，上の問題の制約条件が等利潤曲線 ABで描 かれるならば，解は点Eで与えられよう。ABが独占利潤 $M^{* *}-c$ に対応 
するのであれば，審查精度の引き上げによる独占均衡点 $\mathrm{A}$ からEへの移行は， 供給者の利潤を損なうことのない期待効用の増大（A D”から C Dへのシフ ト）を意味する。審査の限界的な強化は，等利潤曲線上で $(1-f) c$ の費 用節約をむたらす。これは状態 2 の消費者が保険者によって選別されること でもたらされ，この分だけ保険者は供給者への支払いを減少させることがで き，貨幣の効用を増大させることが可能となる。同時に審査の強化は状態 2 の消費がもたらす期待負効用を $(1-f) s$ だけ減少させる。すなわち審査 の限界的な強化のむたらす限界的な便益は， $u^{\prime}(y)(1-f) c+(1-f) s$ である。一方, 審查の限界費用は効用単位で $u^{\prime}(y) k^{\prime}(a)$ であり, k' $(0)$ が十 分に小さいのであれば，点 Aで等利潤曲線上審査の限界便益は限界費用を上

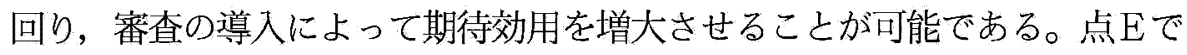
は両者が一致し，期待効用最大化が達成される。

一般に独占均衡が契約曲線上にないことは明らかであり, 独占均衡と比べ て利潤と期待効用のいずれあが高くなる（たとえば点 $\mathrm{E}^{\prime}$ のような）価格と 審查精度の組を契約曲線上いくらであ見い出すことが可能である。したがっ て審查機構を含む契約の保険者による提案は供給者によって受容され，credibility の欠如によってもたらされる需要誘発の問題は緩和される。供給者が 上述のように独占体であれば，保険者子供給者で交わされる契約は双方の交 渉力に依存するだろう。交渉決裂は独占均衡への逆むどりとなる。すなわち 独占均衡点 $\mathrm{A}$ は，交渉ゲームの威跡点（threat point）である。

以上の分析はきわめて単純であるが，PPOに代表されるような管理医療 保険プランの性格をこの視角から理解できる。医師，あるいは医療機関に対 する独立の審査機構設定や医療行為への佂格付けは，決して公的な規制の形 で「押しつけられる」あのではない。保険者との自発的な交渉で成立するの であり，新しいタイプの管理保険プランがなぜ医師，あるいは医療機関によっ て受け入れられるかをこのモデルは説明している。契約の受容によって供給 者の需要誘発的な行動は抑制されるが，それによって失われる利潤の減少は 供給される財の単価の上昇によって相殺される。それは洒格が真に財を必要 としている消費者の選好を反映したものに近づくことであり，前節でみたも ラル・ハザード問題の解消を意味する。保険者の供給者への期待支払い額は 
減少するわけであり, 状態 2 での消費減少のあたらす直接的効果を含む審査 導入の限界的便益がその限界費用を上回れば，こうした契約関係は双方に有 利なあのであり，この論理は市場で自発的に発生する新しい夕イプの保険プ ランに論拠を提供するのである。

\section{3．消費者に多様性があるモデル}

今までの論議は消費者夕イプを一様と仮定して行われたが，初期所得，状 態に関する確率，選好などの次元で消費者夕イプにバラッキがあるのが一般 的である。保険契約の事前や事後でこのようなバラツキが発生して，保険者 が個々の消費者のタイプを見分けられないとすると，いわゆる逆選択（adverse selection）やモラル・ハザードが完全情報のもとで得られる完全力 バーの保険の実現を阻んでしまう可能性が生ずる。本節では今までのモデル に消費者タイプのバラッキを入れ，この可能性を考慮に入れた分析を行う。

消費者の選好を表わす指標のひとつ，消費の非金銭的な機会費用 $\mathrm{s}$ を，区 間 $(0, \mathrm{~S})$ 上で正值をとる連続な密度関数 $\mathrm{g}(\mathrm{s})$ を持つ確率分布 $\mathrm{G}(\mathrm{s})$ にし たがう確率変数としよう。たとえ金銭的な機会費用がゼロでも購入を控える 消費者が存在しうるとして $0<\mathrm{V}<\mathrm{S}$ とする ${ }^{6)}$ 。保険契約の時点で保険者， 消費者ともに機会費用 $\mathrm{s}$ についての不確実性に直面し，分布 $\mathrm{G}(\mathrm{s})$ 以上の情 報を持っていないが，事後，いわゆる情報の非対称性か現れるとしよう。個々 の消費者は自分の直面している $\mathrm{s}$ を知るが，保険者は依然として無知のまま である。したがって各消費者について事後に保険者が知りうるのは，その消 費者が購入を決意したかいなかであり，もし購入を決意して選好あるいはニー

6) このようにモデル化する理由は，ただちにホテリング・タイブの製品差別化モデルへ移行 しやすいためである。そうすることで，後に（4 節および付録 $2 て ゙ ）$ 明らかになるように， 保隃者が複数以上の供給者之契約を交わす状況で，消費者による供給者選択の誘因をどの ように制御するか，適切な分析が可能になる。その場合， $\mathrm{s}$ を当該供給者から購入する非 金銭的な機会費用とすれば，その他の供給者から購入する機会費用は $\mathrm{S}-\mathrm{s}$ となる。生活 もしくは職業上の理由から地域間の移動が頻繁かつ不確実な消費者ほど，こうした状況に 適合していると考えられる。 
ズに関する審查を受ける場合に, 状態 2 之判明して消費を控えるか, 状態 1 と判明する，あしくはどちらとあわからないまま消費を行うのいずれかであ る。したがって保険者はこの 3 つの状況に応じて保障所得を事前に設定する ことになるが，その設定の仕方，保険者之消費者間での費用分担は，明らか に消費者行動（審查を受けるかいなか）を左右し，之れは保険料の水準に影 響を及ぼすことになる。これは前節の議論では現れなかった論点である7゙。

\section{1. 需要関数の導出}

個々の消費者の合理的な購入行動を前提に，この財に対する需要関数を導 出することから議論を始める。保険契約の事後, 機会費用 $\mathrm{s}$ を持つ消費者が 購入を決意するとすれば，その期待効用は，審查の精度 $\mathrm{a}$, 審查の結果状態 2 と判明して消費しない場合の事後所得 $\mathrm{y}_{1}$ および状態 1 と判明するかある いは状態についての情報を得られないまま消費する場合の事後所得 $\mathrm{y}_{2}$ のあ とで, $(1-\mathrm{f}) \mathrm{au}\left(\mathrm{y}_{1}\right)+(1-(1-\mathrm{f}) \mathrm{a})\left(\mathrm{u}\left(\mathrm{y}_{2}\right)-\mathrm{s}\right)+\mathrm{fV}$ と表される。 一方購入しないと決めて審査を受けない場合の事後所得を $\mathrm{y}_{0}$ とすれば, $\mathrm{u}$ （yo）の効用を得る。そこでこの 2 つの選択が無差別となる消費者のタイプ,

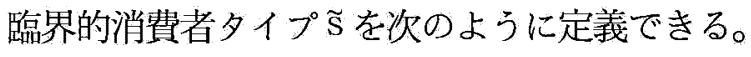

(1) $(1-f) a u\left(y_{1}\right)+(1-(1-f) a)\left(u\left(y_{2}\right)-\tilde{s}\right)+f V=u\left(y_{0}\right)$

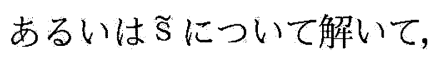

7) 保険契約の事後に各消費者の状態が保険者に知られない状況として，ここでモデル化した あのの他に，たとえば健康状態に関する何らかの異常な自覚症状が被保険者ごとに異なっ て立ち現れるということがあろう。自覚症状はニーズに対するノイズを含んだシグナルで あるから，各消費者は受け取ったシグナルのあとで罹病の確率（このモデルにおけるf） を推定し，受診と受診しない場合の期待効用をそれぞれ算定した上で，受診すべきかいな かを決定する。拙稿（1991）は, こうした受診行動と, 医療サービスが診断と治療から構 成される点などを踏まえた上で, きわめて一般的な形で保険設計の問題を考察し, 最適解 の性質を検討している（ただしそこでは医師による誘発需要の問題とその可能性が消費者 の受竛行動に及ぼす影響についての分析はなされていない)。 
$\widetilde{s}=\left\{(1-f) a u\left(y_{1}\right)+(1-(1-f) a) u\left(y_{2}\right)-u\left(y_{0}\right)+f V\right\} /(1-(1-$ f) a)

を得る。このとき $\mathrm{S} \leqq \widetilde{\mathrm{s}}$ の消費者のみ購入を決意して審査を受けることにな るのは明らかであり，したがって審査を受ける消費者数は $\mathrm{G}(\widetilde{\mathrm{s}})$ となる。こ のうち実際に消費を行うのは $D=(1-(1-f) a) G(\widetilde{s})$ であり，これが供 給者の直面する需要関数である（な打臨界的消費者夕イプの意思決定が需要 に及ぼす効果は無視して差し支えない)。

需要関数の性質は明らかであろう。消費者による自己負担が増大，つまり $\mathrm{y}_{0}$ に比べて $\mathrm{y}_{1}$ あるいは $\mathrm{y}_{2}$ が低下すれば，相対的に機会費用の高い消費者ほ

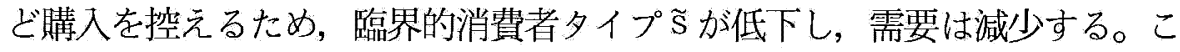
のとき保険者は財の購入費用そのものに加え審査費用の節約を図ることが可 能であり，それによって保険料を引き下げることができる。しかし貨幣の限 界効用が貨幣消費量の増大につれて隇少するため，いわゆる所得効果によっ て保険料の引き下げは需要を増大させ，自己負担導入による費用節約の当初 の効果は緩和される。

次に審查の精度が需要に及ぼす効果をみるために，審查を受ける消費者が その結果いかんにかかわらず同じ所得を保障されるとしよう $\left(\mathrm{y}_{1}=\mathrm{y}_{2}\right)_{0}$ 。こ のとき精度が高まれば状態 2 での消費が抑制され，その機会費用が低下する ため, 臨界的消費者夕イプ $\widetilde{\mathrm{S}}$ は上昇し, 購入を決意して審査を受ける消費者 の数は増大する。この効果は $\partial \mathrm{G}(\tilde{\mathrm{s}}) / \partial \mathrm{a}=\mathrm{g}(\tilde{\mathrm{s}}) \tilde{\mathrm{s}}(1-\mathrm{f}) /(1-(1-$ f）a）上表される。一方で状態 2 の消費者が振い分けられる効果は - (1f) $\mathrm{G}(\widetilde{\mathbf{S}})$ である。よって $\partial \mathrm{D} / \partial \mathrm{a}=(1-(1-\mathrm{f}) \mathrm{a}) \partial \mathrm{G}(\widetilde{\mathrm{s}}) / \partial \mathrm{a}-(1-$ f) $G(\widetilde{\mathrm{S}})=(\mathrm{g}(\widetilde{\mathrm{s}}) \widetilde{\mathrm{s}}-\mathrm{G}(\widetilde{\mathrm{s}}))(1-\mathrm{f})$ より, 精度の上昇で供給者への需要が 増大するのは，前者の効果が後者のそれを上回る，したがって $\mathrm{g}(\widetilde{\mathrm{s}}) \widetilde{\mathrm{s}}>\mathrm{G}$ (令) あるいは $\mathrm{g}(\widetilde{\mathrm{s}}) \widetilde{\mathrm{s}} / \mathrm{G}(\widetilde{\mathrm{s}})>1$ の場合である。つまり精度の上昇が需要を増 大させるかどうかは，臨界的消費者夕イプのもとでの分布関数の形状あるい は弾性值に依存することがわかる。 


\section{2. 最適保険問題}

保険者の直面している制約条件は 2 つる。ひとつは供給者に一定以上の 利潤を保証することであり，その留保利潤を II とすれば,

(2) $(P-c)(1-(1-f) a) G(\widetilde{s}) \geqq I I$

ここで $\hat{P}=P(1-(1-f) a) G(\widetilde{s})$ とおけば, $\hat{P}-(1-(1-f) a) c G$ $(\widetilde{\mathrm{S}}) \geqq \mathbb{I I}$ である。

あうひとつは予算制約式であり,

(3) $Y-\hat{P}-G(\widetilde{s}) k(a) \geqq(1-G(\widetilde{s})) y_{0}+\left\{(1-f) a_{1}+(1-(1-f) a) y_{2}\right\}$ $\mathrm{G}(\widetilde{\mathrm{s}})$

と表すことができよう。保険者の問題は以上の制約のあとで事前の期待効用,

(4) $W=(1-G(\widetilde{s})) u\left(y_{0}\right)+\left\{(1-f) a u\left(y_{1}\right)+(1-(1-f) a) u\left(y_{2}\right)\right\}$ $\mathrm{G}(\widetilde{\mathrm{s}})+\mathrm{fG}(\widetilde{\mathrm{s}}) \mathrm{V}-(1-(1-\mathrm{f})$ a $) \int_{0}^{\widetilde{\mathrm{s}}} \mathrm{sdG}(\mathrm{s})$

を最大とする $\mathrm{P}, \mathrm{y}_{0}, \mathrm{y}_{1}, \mathrm{y}_{2}, \mathrm{a}$ を求めることである。

最適解ではいずれの制約式も等号で成立することは明らかである。仮によ゙ ちらかが不等号で成立しているとすれば，臨界的な消費者夕イプを変えるこ となく，期待効用を増大させるような事後所得の調整が可能である。したがっ

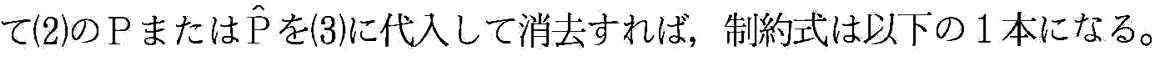

(5) $\mathrm{Y}-\mathbb{I}-\{(1-(1-\mathrm{f}) \mathrm{a}) \mathrm{c}+\mathrm{k}(\mathrm{a})\} \mathrm{G}(\tilde{\mathrm{S}})=$ $(1-G(\tilde{\mathbf{s}})) y_{0}+\left\{(1-f) a y_{1}+(1-(1-f) a) y_{2}\right\} G(\widetilde{s})$

さらに最適解では，審查を受ける消費者が審查の結果消費を行う，行わな いとは独立に同じ所得を保障されること $\left(\mathrm{y}_{1}=\mathrm{y}_{2}\right)$ を，容易に証明できる。 期待効用と制約式が加法的な形をしていることで，臨界的な消費者夕イプと 
審查を受けない消費者の事後所得を所与とする部分問題を考えることができ る。そこで $\mathrm{y}_{1} \neq \mathrm{y}_{2}$ のとき，審査の結果状態 2 と判明する場合の貨幣の限界 効用と状態 1 と判明するか，あるいは不明のまま消費が起こる場合の貨幣の 限界効用が等しくなるように所得を再配分することで，審查を受ける場合の 期待効用は増大する。これによって臨界的な消費者タイプが変化して需要む 増大するが，これを相殺するように審査を受けない場合の所得を相対的に増 加させることが可能であり，結果として期待効用の増大をみることができる。 したがって $\mathrm{y}_{1}=\mathrm{y}_{2}$ である。

次に a を所与としたとき, 最適保険のもとでの, 審查を受ける消費者の事 後所得 $\mathrm{y}_{1}^{*}$ と審查を受けない（したがって購入もしない）消費者の事後所得 y。 について以下の関係が成立することを確認したい。

命題 1 最適保険のもとで, 購入を決意し審查を受ける消費者の自己負担額 はゼロではないが，その額は消費および審查にともなう期待費用よりあ低い。 したがって審査を受けない消費者も保険料の形でその費用を分担することに なる。すなわち，次の関係が成立している：(1-(1-f) a ) $c+k(a)>$ $\mathrm{y}_{0}{ }^{*}-\mathrm{y}^{*}>0$ 。

図 2

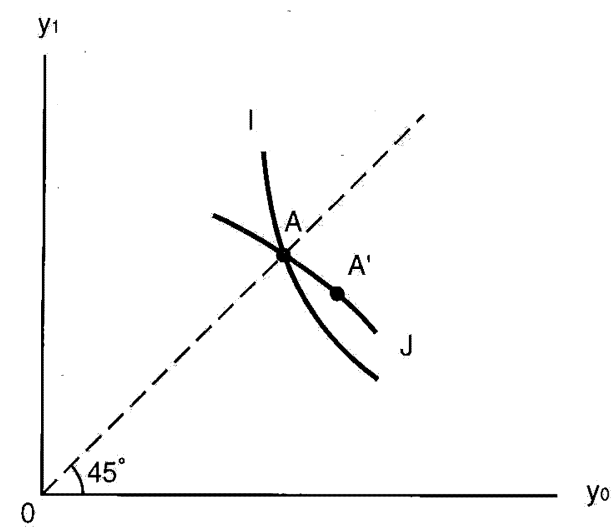

この命題の代数的な証明は付録 1 にゆずるが，まず完全保険が成立しない 理由は図 2 を用いて次のように説明されよう。図 2 の縦軸は $\mathrm{y}_{1}$, 横軸は $\mathrm{y}_{0}$ 
をそれぞれ表している。点 $\mathrm{A}$ は完全保険の場合の所得 $\mathrm{y}_{0}=\mathrm{y}_{1}=\mathrm{Y}-\mathrm{II}-\{(1-$ $(1-f) a) c+k(a)\} G(\widetilde{s}) （ た た ゙ し ~ \widetilde{s}=f V /(1-(1-f) a) ）$ を表し， 曲線 I はAを通過する期待効用の無差別曲線であり, 曲線 J は予算制約式を 示している。点Aの近傍で各曲線がこのような位置関係となる理由は簡単で ある。点Aから予算制約式にそって自己負担を導入していくと臨界的な消費 者タイプのシフトによって需要が減少し，消費および審查の費用がその分だ け節約されるため， $y_{1}$ を 1 円滅少させることで $\mathrm{y}_{0}$ を $\mathrm{G}(\widetilde{\mathrm{S}}) /(1-\mathrm{G}(\widetilde{\mathrm{S}}))$ 円 より多く増加させることができる。一方で, 点Aでの無差別曲線の傾き（限 界代替率) は一 $(1-G(\widetilde{S})) / G(\widetilde{S})$ である。したがって自己負担の導入によ る保険料の節約（点A`への移行）は明らかに期待効用を増大させると考え

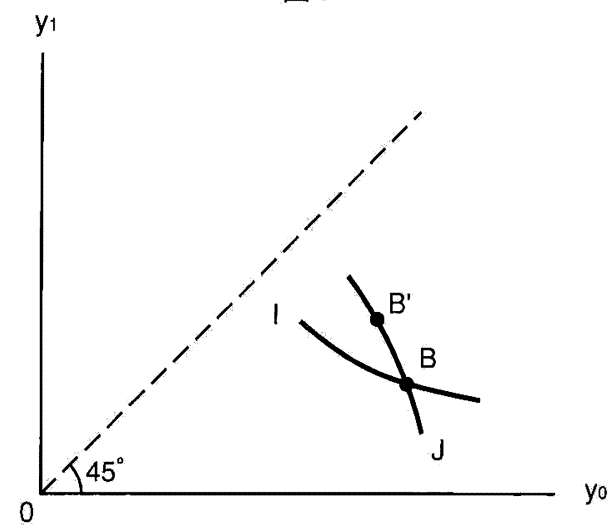

られる。

消費亡審查の費用が審査を受けた消費者によって完全に自己負担されるこ

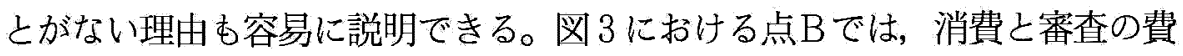
用は審查を受ける消費者によってすべて自己負担され， $\mathrm{y}_{0}-\mathrm{y}_{1}=(1-(1-$ f) a ) $c+k(a)$ である。このとき審查を受ける消費者の事後所得の方が低 く, それだけ貨幣の限界効用が高くなるため, 無差別曲線 I の傾きは一（1$\mathrm{G}(\widetilde{\mathrm{S}})) / \mathrm{G}(\widetilde{\mathrm{S}})$ よりあ緩やかである。ところが予算制約式にそって自己負担を 減少させ保険料を増大させる場合， $\mathrm{y}_{1}$ を 1 円増加させることで犠牲となる $\mathrm{y}_{0}$ は $\mathrm{G}(\widetilde{\mathrm{s}}) /(1-\mathrm{G}(\widetilde{\mathrm{s}}))$ 円である。したがって図 2 と対照的な論理で, 自己 負担の減少による保険料の増大 (点B'への移行) は明らかに期待効用を増 
大させるのである。

以上の分析は供給者との契約という観点であ興味深い含意がある。供給者 が独占体であり，契約前のシステムが審查なしの出来高払いで完全カバーの 保険であったとしょう。消費者が保険に加入していれば G(fV) の需要を確 保できるため，供給者は保険加入の誘因を消費者に保証するギリギリのとこ ろまで価格を引き上げることが可能であり，保険システムを利用することで 高利潤を確保できよう ${ }^{8)}$ 。ところが上の分析によれば（任意の審查精度のむ とで，費用の一定割合を消費者が負担するタイプの保険プランを導入する ことで，供給者にさらに高い利潤を約束でき，消費者の期待効用も高めるこ とが可能である。つまり供給者を「伝統的な」保険システムに依存した既得 権益から引き離すことができるのである。

\section{3. 最適審查水準}

最適解のもとで選択される審查精度がどのように特徵付けられるかを検討 しよう。初めに精度の上昇が予算制約式にそって保險料にどのような効果を あたらすかをみる。すでに確認したように，精度の上昇は審查を受ける人々 を限界的に $\partial \mathrm{G}(\widetilde{\mathrm{s}}) / \partial \mathrm{a}=\mathrm{g}(\widetilde{\mathrm{s}}) \tilde{\mathrm{s}}(1-\mathrm{f}) /(1-(1-\mathrm{f}) \mathrm{a})$ だけ増大さ せるので，審查を受ける消費者 1 人当たりの審查および消費の期待費用のう ち保険料加賄われる分を $\mathrm{L}=(1-(1-\mathrm{f}) \mathrm{a}) \mathrm{c}+\mathrm{k}(\mathrm{a})-\mathrm{y}_{0}+\mathrm{y}_{1}$ とすれ ば，審査の高度化は $\operatorname{Lg}(\widetilde{\mathrm{s}}) \widetilde{\mathrm{s}}(1-\mathrm{f}) /(1-(1-\mathrm{f}) \mathrm{a})$ の保険料増大を あたらす。これは需要が非弾力的であった前節の議論では現れなかった効果 である。これに審查費用の増大 k’(a) $\mathrm{G}(\widetilde{\mathrm{S}})$ を加え，審査が状態 2 での消費を 抑制する効果 $-(1-f) c \mathrm{G}(\widetilde{\mathrm{S}})$ を考慮すれば，審查精度が保険料にもたら

8 ）独占的な供給者が審查なしに完全カバーの保険システムを利用して（消費者の保険加入の 意思決定の前に）価格付けを行う之すれば，厳密には，消費者に保険加入の誘因を保証す る次の条件,

$$
\begin{aligned}
\mathrm{u}(\mathrm{Y}- & \mathrm{PG}(\mathrm{fV}))+\mathrm{fG}(\mathrm{fV}) \mathrm{V}-\int_{0}^{\mathrm{fV}} \mathrm{sdG}(\mathrm{s}) \geqq \\
& (1-\mathrm{G}(\widetilde{\mathrm{s}})) \mathrm{u}(\mathrm{Y})+\mathrm{G}(\widetilde{\mathrm{s}}) \mathrm{u}(\mathrm{Y}-\mathrm{P})+\mathrm{fG}(\widetilde{\mathrm{s}}) \mathrm{V}-\int_{0}^{\widetilde{s}} \mathrm{sdG}(\mathrm{s}) \\
& (\text { ただし, } \widetilde{\mathrm{s}}=\mathrm{u}(\mathrm{Y}-\mathrm{P})-\mathrm{u}(\mathrm{Y})+\mathrm{fV})
\end{aligned}
$$

を満足する最大の価格が選択されることになる。 
す効果は $\operatorname{Lg}(\tilde{\mathrm{s}}) \widetilde{\mathrm{s}}(1-\mathrm{f}) /(1-(1-\mathrm{f}) \mathrm{a})+\left(-(1-\mathrm{f}) \mathrm{c}+\mathrm{k}^{\prime}(\mathrm{a})\right) \mathrm{G}$ (灾) となろう。一方, 状態 2 の消費が回避されることによる直接的な期待効 用の増分は，(1-f ) $\int_{0}^{\widetilde{s}} \mathrm{sdG}(\mathrm{s})$ である。したがって最適解のもとで保険料 が 1 円節約されることであたらされる期待効用の増分を $\lambda$ と定義すると, 最 適な審查水準 $\mathrm{a}$ *が正值（内点解）をとるならば，それは以下のように決定 されるであろう。

(6) $(1-\mathrm{f}) \int_{0}^{\widetilde{s}} \mathrm{sdG}(\mathrm{s})-\lambda\left[\operatorname{Lg}(\widetilde{\mathrm{s}}) \widetilde{\mathrm{s}}(1-\mathrm{f}) /\left(1-(1-\mathrm{f}) \mathrm{a}^{*}\right)+\right.$ $\left.\left(-(1-\mathrm{f}) \mathrm{c}+\mathrm{k}^{\prime}\left(\mathrm{a}^{*}\right)\right) \mathrm{G}(\widetilde{\mathrm{s}})\right]=0$

しかしながら一般に最適保険のもとで審査が実施される（a*>0 となる） かどうかは必ずしも明らかではない。相対的に審査の限界費用が高ければ, 審查が実施されない可能性すある。そこでまず総費用 $C=\{(1-(1-\mathrm{f})$ a) $\mathrm{c}+\mathrm{k}(\mathrm{a})\} \mathrm{G}(\tilde{\mathrm{S}})$ が精度の上昇につれてどのような影響を受けるか, 精度 水準がゼロの場合を出発点にして検討してみよう。

$\partial \mathrm{C} / \partial \mathrm{a}=\{(1-(1-\mathrm{f}) \mathrm{a}) \mathrm{c}+\mathrm{k}(\mathrm{a})\} \mathrm{g}(\widetilde{\mathrm{s}}) \widetilde{\mathrm{s}}(1-\mathrm{f}) /(1-(1-\mathrm{f})$ a) $-(1-\mathrm{f}) \mathrm{cG}(\widetilde{\mathrm{s}})+\mathrm{k}^{\prime}(\mathrm{a}) \mathrm{G}(\widetilde{\mathrm{s}})$ から，これを $\mathrm{a}=0$ で評価して， $\partial \mathrm{c} /$ $\left.\partial \mathrm{a}\right|_{\mathrm{a}=0}=(\mathrm{g}(\widetilde{\mathrm{S}}) \widetilde{\mathrm{s}}-\mathrm{G}(\widetilde{\mathrm{S}}))(1-\mathrm{f}) \mathrm{c}+\mathrm{k}^{\prime}(0) \mathrm{G}(\widetilde{\mathrm{S}})$ を得る。精度の上昇が 総費用をどのように变化させるかは, 明らかに精度上昇が審査を受ける人々 の数にもたらす効果に強く依存している。すなわち弾性值 $\mathrm{g}(\widetilde{\mathrm{s}}) \widetilde{\mathrm{s}} / \mathrm{G}(\widetilde{\mathrm{s}})$ が 1より小さいならば，審查需要の増大がもたらす費用の増分は審查による振 い分けの効果によって優越されるだろう。このとき $\mathrm{k}^{\prime}(0)$ が十分小さいなら ば，総費用はむしろ減少し，明らかに審查の実施が望ましい。一方で弾性值 $\mathrm{g}(\widetilde{\mathrm{S}}) \widetilde{\mathrm{s}} / \mathrm{G}(\widetilde{\mathrm{S}})$ が 1 より大きければ，審查需要の伸びは振い分けの効果を越 えるため, 総費用はむしろ増大する。したがって完全カバーの保険を制度と して前提する限り，審査の実施が望ましいかどうかは確定できないことにな る。ただし最適保険のもとでは費用がすべて保険料で賄われるわけではない こと，および状態 2 での消費抑制がもたらす直接的効果の存在によって，総 費用の増大が必ずしも審査導入の非最適性を意味するとは限らないことに留 意すべきである。いずれにしても，前節の議論に比べ明白な結論を導きにく 
いのは，消費者に多様性を仮定することで番査精度や事後所得に対して弾力 的な需要関数が分析に現れたことによっている。

なお以上の分析からきわめて興味深いことを観察できる。PPOのひとつ の特徽は，医師，医療機関に対して患者を確保する見返りとして，医療行為 の審查を強化することに加え，価格割引を要請することである。本節のモデ ルでこれは弾性值 $\mathrm{g}(\widetilde{\mathrm{S}}) \widetilde{\mathrm{s}} / \mathrm{G}(\widetilde{\mathrm{S}})$ が 1 より大きい状況に対応する。この場合, 先に述べたように番査の導入は供給者に対する需要を増大させるため，供給 者は容易にサービス当たり価格の引き下げに応じるのである。このとき総費 用も増大するが，一部自己負担によってその効果はいくぶん相殺され，また 仮に保険料が増大するにせよ，状態 2 での消費抑制があたらす直接的効果が 優越すれば，審査の導入・強化は期待効用の増大に帰結し，消費者もまたこ のような保険プランを受け入れるのである。

\section{4. 結 語}

医療サービスに代表される財・サービスの市場では，その選好やニーズに ついての情報は，消費者側よりもむしろ供給者側に偏在している。そのため 供給者は, ニーズの低い消費者にも購入をすすめて利潤の増大を図るという 機会主義的な行動への誘因に，常にさらされているといえるだろう。たとえ 真の選好を消費者に伝え，ニーズの高い消費者を選んで供給する戦略が高利 潤をもたらす場合であ，こうした戦略は credible ではなく，結局は情報の 伝達が起こらないまま，ニーズの低い（あるいは皆無の）消費者にあ供給す る戦略が採用される。そして，こうしたトラップを回避するメカニズムの担 い手として，消費者の利害を代表するか，あるいは中立的な主体である保険 者が登場することになる。保険者は消費者ニーズに対する審査機構と供給価 格から成る契約を供給者と交渉し，消費者に対しては供給者との契約形態， 保険料，自己負担率などを盛り込む保険プランを提示する。小論では，この ようなプランが供給者と消費者双方に従来型の保険システムを淩駕するメリッ トをむたらす可能性を検討したのである。

まず保険契約事後にわかる消費者タイプ（小論では受診の非金銭的な機会 
費用）に多様性がない場合を吟味し，審査精度に依存する審査費用関数の形 状しだいでは，審查機構の構築と供給価格の提示を含む保険者之供給者の交 渉は，必ず供給者と消費者双方に望ましい結果をむたらすことが明らかにさ れた。そのさい事後の状態に依存することなく等しい所得が各消費者に保障 される，いわゆる完全カバ一の保険が成立することになる。しかし消費者夕 イプに多様性があり，保険者が事後に各消費者のタイプを見分けることがで きず，タイプに依存した保険契約の設計が不可能であれば，最適保険は購入 を決意して審査を受ける消費者に一部自己負担を課すすのとなる。この場合， むし最適契約で審查が実施され，その機構の構築が供給者への実質的な需要 （実際に財を購入する消費者の数）を増大させるのであれば，供給者は従来 のシステムのあとでよりあ低い価格での供給に応じるのであり，これはPPO に共通して観察される「価格割引」に対応するあのである。

なお小論の分析では，保険者がひとりの供給者とのみ供給契約を結ぶとい う状況を設定しており，消費者には他の供給者加ら購入する機会は与えられ ていない。したがって管理医療保険プランが被保険者による医師選択の自由 に制限を与える傾向にあることについて，内生的な説明を行うことはこのま までは無理である。そこで小論を結ぶにあたって，この点の考察が今までの モデルを若干拡張して解釈し直せば，ある程度可能となることに触れておき たい（分析の詳細は付録 2 で展開される）。そのために，非金銭的な機会費 用 $\mathrm{s}$ の分布を支持する区間の両端 0 とSにそれぞれひとつの供給者が立地し ていると考元，タイプ S の消費者が 0 に位置する供給者から購入する機会費 用は $\mathrm{s} ， \mathrm{~S}$ に位置する供給者加ら購入する機会費用は $\mathrm{S}-\mathrm{s}$ となると想定す るのである。これによってホテリング・タイプのモデルが得られる。保険者 はいずれの供給者とも契約を交渉するが，供給者数の増大にともなう取引費 用や審査機構の管理・運営費用の増大などによって, すべての供給者の顧客 に一律の審査を行うことは困難であるとし, 審查機構の構築を契約に含める 供給者を主供給者，そうでない供給者を副供給者と呼ぼう（どちらを主供給 者とするかは，各供給者の財供給の限界費用之消費者の機会費用の分布に依 存すると考えられるが，ここではこの問題に立ち入らない)。保険契約の時 点で, 消費者は購入の機会費用についての不確実性に直面しているが，事後 
には確定し，いずれの供給者加ら購入するかを意思決定するすのとしよう。 このとき保険者は，消費者がどの供給者を選択したかに依存する形に事後所 得を設定し，その選択行動を間接的に制御することが可能である。

最適保険のもとでは, 購入および審査の期待費用が他よりあ高くなる供給 者を選んだ消費者の負担が相対的に高く設定される。つまりもし主供給者の 消費者 1 人当たり期待購入費用之審查費用の和が，副供給者のそれょりも低 ければ，主供給者を選択する消費者は優遇されることになる。しかしながら， 負担の格差が費用の格差を越えることはなく，したがって保険が成立するの である。このことは，当初，被保険者が傘下以外の医師に受診する誘因を厳 しく制限していたPPOの多くが，制限をいくぶん緩和させることでプラン を消費者にいっそう魅力的なすのとしていった点に対応している。なお，副 供給者の限界費用が主供給者のそれを上回っているとき，審査導入の限界費 用 $\mathrm{k}^{\prime}(0)$ が相刘的に十分小さいならば，主供給者での審查実施が望ましい屯 のとなることはほぼ明らかであろう。しかしながら，最適保険，最適審査水 準のもとで主供給者の期待費用が副供給者の期待費用を下回るかどうかは, 一般には不確定なのである。

\section{付録 1 （命題 1 の証明）}

本文よりすでに $\mathrm{y}_{1}=\mathrm{y}_{2}$ は明らかである。したがって(1) (4)，(5)は以下のよ うになる。

$$
\begin{aligned}
& \text { (A 1) } \widetilde{s}=\left\{u\left(y_{1}\right)-u\left(y_{0}\right)+f V\right\} /(1-(1-f) a) \\
& \text { (A } 2) ~ W=(1-G(\widetilde{\mathbf{s}})) \mathrm{u}\left(\mathrm{y}_{0}\right)+\mathrm{G}(\widetilde{\mathbf{s}}) \mathrm{u}\left(\mathrm{y}_{1}\right)+\mathrm{fG}(\widetilde{\mathbf{s}}) \mathrm{V}-(1-(1-\mathrm{f}) \mathrm{a}) \\
& \int_{0}^{\widetilde{s}} \operatorname{sdG}(\mathrm{s}) \\
& \text { (A 3) } Y-I I-\{(1-(1-f) \text { a }) c+k(a)\} G(\widetilde{s})=(1-G(\widetilde{s})) y_{0} \\
& +\mathrm{G}(\tilde{\mathrm{S}})_{\mathrm{y}_{1}}
\end{aligned}
$$


問題は制約条件（A 3 ）のもとで（A 2 ）の期待効用を最大にすることで ある。さしあたって精度 $\mathrm{a}$ を所与とすれば， $\mathrm{y}_{0}$ と $\mathrm{y}_{1}$ に関する最大化の必要 条件は，正の $\lambda$ に対して以下が成立することである（以下で最適解を明示す る*は省略する)。
(A 4) $(1-\mathrm{G}(\widetilde{\mathrm{s}})) \mathrm{u}^{\prime}\left(\mathrm{y}_{0}\right)-\lambda\left[\mathrm{Lg}(\widetilde{\mathrm{s}})\left(-\mathrm{u}^{\prime}\left(\mathrm{y}_{0}\right) /(1-(1-\mathrm{f}) \mathrm{a})\right)\right.$ $+1-\mathrm{G}(\widetilde{\mathrm{S}})]=0$

(A 5 ) $\quad \mathrm{G}(\widetilde{\mathrm{s}}) \mathrm{u}^{\prime}\left(\mathrm{y}_{1}\right)-\lambda\left[\mathrm{Lg}(\widetilde{\mathrm{S}}) \mathrm{u}^{\prime}\left(\mathrm{y}_{1}\right) /(1-(1-\mathrm{f}) \mathrm{a})+\mathrm{G}(\widetilde{\mathrm{s}})\right]=0$

ただし，すでに本文であ定義されているが，入は最適保険のもとで保険料 が 1 円節約されることであたらされる期待効用の増分であり， $\mathrm{L}=(1-(1-$ f) a ) $c+k(a)-y_{0}+y_{1}$ は，審查を受ける消費者 1 人当たりの期待費用 (1$(1-\mathrm{f}) \mathrm{a}) \mathrm{c}+\mathrm{k}$ (a)のうち保険加らきょ出される分である。

(A 4) と（A 5) より以下を得る。

$$
\begin{aligned}
\lambda & =(1-\mathrm{G}(\widetilde{\mathrm{s}})) \mathrm{u}^{\prime}\left(\mathrm{y}_{0}\right) /\left[-\mathrm{Lg}(\widetilde{\mathrm{s}}) \mathrm{u}^{\prime}\left(\mathrm{y}_{0}\right) /(1-(1-\mathrm{f}) \mathrm{a})+1-\mathrm{G}(\widetilde{\mathrm{s}})\right] \\
& =\mathrm{G}(\widetilde{\mathrm{s}}) \mathrm{u}^{\prime}\left(\mathrm{y}_{1}\right) /\left[\mathrm{Lg}(\widetilde{\mathrm{s}}) \mathrm{u}^{\prime}\left(\mathrm{y}_{1}\right) /(1-(1-\mathrm{f}) \mathrm{a})+\mathrm{G}(\widetilde{\mathrm{s}})\right]
\end{aligned}
$$

命題が成立しないとして $\mathrm{y}_{0} \leqq \mathrm{y}_{1}$ とすれば，明らかに L >0 である。この とき上式より $\mathrm{u}^{\prime}\left(\mathrm{y}_{0}\right)<\lambda<\mathrm{u}^{\prime}\left(\mathrm{y}_{1}\right)$ を得るが，これは明らかに矛盾である。 したがって $\mathrm{y}_{0}>\mathrm{y}_{1}$ がしたがう。次に $\mathrm{L} \leqq 0$ を仮定すれば， $\mathrm{u}^{\prime}\left(\mathrm{y}_{1}\right)<\lambda<\mathrm{u}$ ，

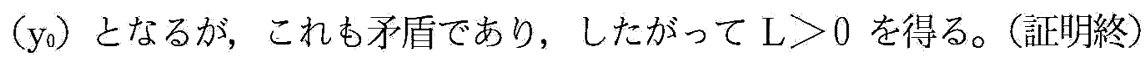

\section{录 2}

消費者タイプの分布上，0 亿位置する供給者を主供給者とし，S S 位置す る供給者を副供給者とする。また，副供給者を選択する消費者の二ーズに関 する審查は行われないるのとする（ただし，これについてはすでに最適な選 択がなされているとする)。さらに，いずれのタイプの消費者む必ずどちら 
かの供給者で審査を受けるか，あるいは購入するあのとする。このとき，主 供給者で審查を受ける場合の事後所得を $\mathrm{y}_{0}$, 副供給者から購入する場合の 事後所得を $\mathrm{y}_{\mathrm{s}}$ とすれば，主供給者における審査精度 $\mathrm{a}$ のあとで，主供給者 を選択する消費者の期待効用は $\mathrm{u}\left(\mathrm{y}_{0}\right)+\mathrm{fV}-(1-(1-\mathrm{f}) \mathrm{a}) \mathrm{s}$ ，副供給 者を選択する消費者の期待効用は $\mathrm{u}\left(\mathrm{y}_{\mathrm{s}}\right)+\mathrm{fV}-(\mathrm{S}-\mathrm{s})$ となる。したがっ て選択が無差別となる臨界的な消費者のタイプは,

(A 6 ) $\quad \tilde{s}=\left(s+u\left(y_{0}\right)-u\left(y_{s}\right)\right) /\{1+(1-(1-f) a)\}$

と定義され， $\mathrm{s} \leqq \widetilde{\mathrm{s}}$ の消費者は主供給者を，そうでない消費者は副供給者を 選択する。

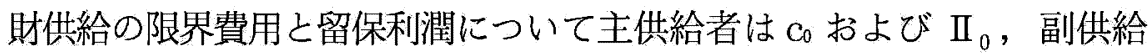
者は $\mathrm{c}_{\mathrm{s}}$ および $I_{\mathrm{s}}$ とし，それぞれの供給価格を $\mathrm{P}_{0}, \mathrm{P}_{\mathrm{s}}$ とすれば，各供給者 に契約を受容させるための制約条件は，主供給者については，

(A 7$)\left(P_{0}-c_{0}\right)(1-(1-f)$ a $) G(\widetilde{s}) \geqq \Pi_{0}$

副供給者については,

(A 8$) \quad\left(P_{s}-c_{s}\right)(1-G(\widetilde{S})) \geqq \Pi_{s}$

と与えられる。一方で保険者の予算制約式は，

(A 9) $\quad G(\widetilde{\mathbf{S}}) y_{0}+(1-G(\widetilde{\mathbf{S}})) y_{s} \leqq Y-\left\{P_{0}(1-(1-f) a)+k(a)\right\} G(\widetilde{\mathbf{S}})-$ $P_{s}(1-G(\widetilde{s}))$

である。これらの制約のもとで保険者は，期待効用

$$
\begin{aligned}
W= & G(\widetilde{\mathbf{s}}) u\left(y_{0}\right)+(1-G(\tilde{s})) u\left(y_{s}\right)+f G(\widetilde{s}) V-(1-(1-f) a) \int_{0}^{\widetilde{s}} s d G \\
& (s)-\int_{\widetilde{s}}^{s}(S-s) d G(s)
\end{aligned}
$$


を最大とする $\mathrm{P}_{0}, \mathrm{P}_{\mathrm{s}}, \mathrm{y}_{0}, \mathrm{y}_{\mathrm{s}}, \mathrm{a}$ を選択する。

最適解では制約はすべて等号で成立するので，（A 7 )と (A 8) から $\mathrm{P}_{0}$, $P_{s}$ を消去して（A 9) に代入し，

(A10) $\mathrm{Y}-\Pi_{0}-\Pi_{\mathrm{s}}-\left\{\mathrm{c}_{0}(1-(1-\mathrm{f}) \mathrm{a})+\mathrm{k}(\mathrm{a})\right\} \mathrm{G}(\widetilde{\mathrm{s}})-\mathrm{c}_{\mathrm{s}}(1-\mathrm{G}(\widetilde{\mathrm{s}}))$ $=\mathrm{G}(\widetilde{\mathrm{s}})_{\mathrm{y}_{0}}+(1-\mathrm{G}(\widetilde{\mathrm{s}})) \mathrm{y}_{\mathrm{s}}$

を得る。このとき $\lambda$ を付録 1 同様に定義すれば， $\mathrm{y}_{0}$ および $\mathrm{y}_{\mathrm{s}}$ に関する最適 の必要条件は以下のように与えられよう。

(A11) $\mathrm{G}(\tilde{\mathrm{s}}) \mathrm{u}^{\prime}\left(\mathrm{y}_{0}\right)-\lambda\left[\mathrm{Lg}(\tilde{\mathrm{s}}) \mathrm{u}^{\prime}\left(\mathrm{y}_{0}\right) /\{1+(1-(1-\mathrm{f}) \mathrm{a})\}+\mathrm{G}(\tilde{\mathrm{s}})\right]$ $=0$

(A12) $(1-\mathrm{G}(\widetilde{\mathrm{s}})) \mathrm{u}^{\prime}\left(\mathrm{y}_{\mathrm{s}}\right)-\lambda\left[\mathrm{Lg}(\widetilde{\mathrm{s}})\left(-\mathrm{u}^{\prime}\left(\mathrm{y}_{\mathrm{s}}\right) /\{1+(1-(1-\mathrm{f}) \mathrm{a})\}\right)\right.$ $+1-\mathrm{G}(\tilde{\mathrm{s}})]=0$

ここで $\mathrm{L}=\mathrm{y}_{0}-\mathrm{y}_{\mathrm{s}}+\mathrm{c}_{0}(1-(1-\mathrm{f}) \mathrm{a})+\mathrm{k}(\mathrm{a})-\mathrm{c}_{\mathrm{s}}$ である。

これより 3 節の命題 1 に対応して，以下の成立することがわかる（以下で 最適解を明示する*は省略してある)。

命題 2 最適保険のあとで $c_{0}(1-(1-f) a)+k(a)-c_{s} \geqq 0$ ならば, $0 \leqq \mathrm{y}_{\mathrm{s}}-\mathrm{y}_{0} \leqq \mathrm{c}_{0}\left(1-(1-\mathrm{f}) \mathrm{a}+\mathrm{k}(\mathrm{a})-\mathrm{c}_{\mathrm{s}}\right.$ （前者が等号のときは後者す等号 で成立)。そうでないならば， $0<\mathrm{y}_{0}-\mathrm{y}_{\mathrm{s}}<\mathrm{c}_{\mathrm{s}}-\left(\mathrm{c}_{0}\{1-(1-\mathrm{f}) \mathrm{a}\}+\mathrm{k}\right.$ (a))。

証明（A11）と（A12）を変形して，

$$
\begin{aligned}
\lambda= & G(\widetilde{\mathrm{s}}) \mathrm{u}^{\prime}\left(\mathrm{y}_{0}\right) /\left[\mathrm{Lg}(\widetilde{\mathrm{s}}) \mathrm{u}^{\prime}\left(\mathrm{y}_{0}\right) /\{1+(1-(1-\mathrm{f}) \mathrm{a})\}+\mathrm{G}(\widetilde{\mathrm{s}})\right] \\
= & (1-\mathrm{G}(\widetilde{\mathrm{s}})) \mathrm{u}^{\prime}\left(\mathrm{y}_{\mathrm{s}}\right) /\left[\mathrm { Lg } ( \widetilde { \mathrm { s } } ) \left(-\mathrm{u}^{\prime}\left(\mathrm{y}_{\mathrm{s}}\right) /\{1+(1-(1-\mathrm{f}) \mathrm{a})\}+\right.\right. \\
& 1-\mathrm{G}(\widetilde{\mathrm{s}})]
\end{aligned}
$$


$c_{0}(1-(1-f) a)+k(a)-c_{s} \geqq 0$ のとき, $y_{0}>y_{s}$ と仮定すれば， $L>0$ 。 したがって u' $\left(\mathrm{y}_{0}\right)>\lambda>\mathrm{u}^{\prime}\left(\mathrm{y}_{\mathrm{s}}\right)$ となるがこれは矛盾である。それゆえ $\mathrm{y}_{0}$ $\leqq \mathrm{y}_{\mathrm{s}}$ である。

このとき $\mathrm{L}<0$ と仮定すれば $\mathrm{u}^{\prime}\left(\mathrm{y}_{0}\right)<\lambda<\mathrm{u}^{\prime}\left(\mathrm{y}_{\mathrm{s}}\right)$ となるが，これは矛 盾である。したがって $\mathrm{L} \geqq 0$ である。次に $\mathrm{c}_{0}(1-(1-\mathrm{f}) \mathrm{a})+\mathrm{k}(\mathrm{a})-\mathrm{c}_{\mathrm{s}}<$ 0 のとき $\mathrm{y}_{0}>\mathrm{y}_{\mathrm{s}}$ かつ $\mathrm{L}<0$ となることあ同様な論法で容易に示すことがで きる。(証明終)

保険者は消費者がどちらの供給者を選んだかによって事後所得に格差を設 け，消費者の選択行動を制御することになるが，そのさい，消費および審査 の期待費用の高い供給者を選択する消費者の負担額が相対的に高く設定され ることになる。とはいえ，負担の格差は費用の格差より屯小さく，したがっ て保険（危険分散）の機能していることがわかる。

aに関する最適の必要条件は, 内点解の場合,

$$
\begin{aligned}
& (1-\mathrm{f}) \int_{0}^{\widetilde{s}} \mathrm{sdG}(\mathrm{s})-\lambda[\operatorname{Lg}(\widetilde{\mathrm{s}}) \widetilde{\mathrm{s}}(1-\mathrm{f}) /\{1+(1-(1-\mathrm{f}) \mathrm{a})\} \\
& \left.+\left(-(1-\mathrm{f}) \mathrm{c}_{0}+\mathrm{k}^{\prime}(\mathrm{a})\right) \mathrm{G}(\widetilde{\mathrm{s}})\right]=0
\end{aligned}
$$

で与えられよう。ここで精度の上昇は副供給者から主供給者へと需要のシフ トをもたらすが，それが保険料に及ぼす効果が $\operatorname{Lg}(\tilde{\mathrm{S}}) \tilde{\mathrm{s}}(1-\mathrm{f}) /\{1+(1-$ (1-f）a）\}であり, 事後所得が最適保険を満たす状況では, 主供給者を 訪れる消費者の期待費用が副供給者のそれを上回る場合，需要のシフトは明 らかに保険料の増大をむたらす（逆は逆である）。この点を考慮すれば，(A 13）に対して 3 節の(6)とほぼ同様の解釈を与えることができよう。

次に，最適解でたしかに正の審查精度が選択される十分条件を検討しよう。 審查の導入が望ましいとわかるのは，それによって総費用 $\mathrm{C}=\left\{\mathrm{c}_{0}(1-(1-\right.$ f) a ) $+k(a)\} G(\widetilde{\mathrm{S}})+c_{s}(1-G(\widetilde{\mathrm{S}}))$ が減少する。すなわち,

$\partial \mathrm{C} /\left.\partial \mathrm{a}\right|_{\mathrm{a}=0}=\left(\mathrm{c}_{0}-\mathrm{c}_{\mathrm{s}}\right) \mathrm{g}(\tilde{\mathbf{S}}) \tilde{\mathbf{s}}(1-\mathrm{f}) / 2-(1-\mathrm{f}) \mathrm{c}_{0} \mathrm{G}(\tilde{\mathbf{S}})+\mathrm{k}^{\prime}(0) \mathrm{G}(\tilde{\mathbf{S}})$ $<0$ 
の場合である。主供給者の限界費用が副供給者のそれを下回り $\left(\mathrm{c}_{0}<\mathrm{c}_{\mathrm{s}}\right)$ ， か

つ k'(0)が十分小さいならば，明らかに審査の導入は望ましい。

しかしながら，最適解でどちらの供給者の期待費用が高くなるかは確定せ

ず，したがってLの符号は一般に不確定である。

\section{参考文献}

〈邦文〉

1) 印南一路（1988）『米国の医療費保障 変わる政策態度と産業構造』, 日本医療文化センター

2）中泉真樹（1991）「医療に扔ける情報の非対称性と保険理論」，未公刊論文。

3 ) 中西悟志, 中泉真樹, 知野哲朗, 铇田忠彦 (1991)「展望 Health Economics の現況」, 経済と経済学 第68号, pp. $1 \sim 34$ 。

〈英文〉

1) Arrow, K. (1963) "Uncertainty and the Welfare Economics of Medical Care", American Economic Review Vol.53, pp.941 973.

2) Darby, M. R. and Karni, E. (1973) "Free Competition and the Optimal Amount of Fraud", Journal of Law and Economics Vol.16, pp.67 88.

3) Enthoven, A. (1988) Theory and Practice of Managed Competition in Health Care Finance, Northholand.

4) Evans, R. G. (1974) "Supplier Induced Demand; Some Empirical Evidence and Implications" in The Economics of Health and Medical Care, pp. 163 173, edited by Perlman, M., Wiley and Sons, New York.

5) Tirole, J. (1988) The Theory of Industrial Organization, MIT Press, Cambridge, Massachusetts.

6) Wolinsky, A. (1993) "Competition in a Market for Informed Experts' Services", Rand Journal of Economics Vol. 24, pp. 380 398. 